\title{
DROGA INICJACJI CHRZEŚCIJAŃSKIEJ W KOŚCIELE STAROŻYTNYM NA PODSTAWIE KATECHEZ CYRYLA JEROZOLIMSKIEGO
}

1. Pojęciem initiare - czyli wtajemniczenie, inicjacja - posługiwali się już starożytni Rzymianie. Oznaczało ono „wejście do wnętrza”, dopuszczenie osoby do udziału w obrzędach pewnej społeczności. Inicjacja warunkowala też przejście człowieka $z$ okresu dzieciństwa do dorosłości ${ }^{1}$. Zagadnieniem inicjacji do dziś interesuje się wiele dyscyplin naukowych, także teologia i pedagogika. Nas interesuje tu głównie ten rodzaj inicjacji, który dotyczy wprowadzenia w chrześcijaństwo, zwłaszcza w początkowym okresie istnienia Kościoła. Liczne źródła, począwszy od informacji przekazanych w Piśmie św. (Dzieje Apostolskie, Listy Apostolskie), w Didache i innych pismach Ojców Kościola, dostarczają wielu informacji na temat inicjacji wczesnochrześcijańskiej; narasta też wciąż literatura wokół tej problematyki ${ }^{2}$. Dla pedagoga religii niezwykle interesujące wydają się być katechezy, które wtajemniczały w życie starożytnego Kościoła.

Jedną z postaci tego Kościoła był Cyryl Jerozolimski, który pozostawił po sobie Katechezy (spisane przez jednego $z$ słuchaczy). Niewątpliwie przedsta-

* Małgorzata Jędrzejewska ukończyła pedagogiczne studia magisterskie na UMK i jest doktorantką w Instytucie Pedagogiki tegoż uniwersytetu oraz studentką teologii w Studium Teologicznym PWT w Warszawie (Sekcja Św. Jana Chrzciciela we Wlocławku).

${ }^{1}$ Por. J. Bagrowicz, Inicjacyjno-katechumenalny ksztalt wychowania jako propozycja na trzecie tysiaclecie, w: Pedagogika u progu trzeciego tysiąclecia, red. A. Nalaskowski - K. Rubacha, Toruń 2001, s. 91.

${ }^{2}$ Por.: E. Bulanda, Wtajemniczenie chrześcijańskie, AK 57 (1965) 129-137; J. Buxakowski, Inicjacja chrześcijańska a życie wewnętrzne, AK 85 (1975) 3-14; Sakramenty wtajemniczenia chrześcijaniskiego, red. J. Kudasiewicz, Warszawa 1981; F.L. Cross, St. Cyril of Jerusalem's lectures on the Christian Sacraments, Crestwood NY 1986 (zawiera tekst grecki); P.F. Bradshaw, Essays in early Eastern Initiation, Bramcote 1988; R. Murawski, Katecheza chrzcielna w procesie wtajemniczenia chrześcijańskiego czasów apostolskich, Warszawa 1990; P.F. Bradshaw, Christian Initiation: A study in diversity, w: The search of the origins of Christian Worship. Sources and methods for the study of early Liturgy, New York 1992, 161-184; E. Yarnold, The Awe - inspiring rites of Initiation: the origins of the RCIA, Collegeville MN 1994; Cz. Krakowiak, Inicjacja w chrześcijaństwie, EK VII 216-220; J. Janicki, Wiajemniczenie chrześcijańskie, w: Stownik Teologiczny, red. A. Zuberbier, Katowice 1998, 654-655. 
wiają one wyraźnie drogę wtajemniczenia w kolejne prawdy wiary. Spróbuję ją odkryć i zaprezentować, a przy okazji odpowiedzieć na kilka pytań, które wyłaniają się z refleksji nad życiem w starożytnym Kościele i odnoszą się do warunków dzisiejszych, także do współczesnego przekazu wiary. W jakim środowisku głoszone były Katechezy Cyryla Jerozolimskiego? Czy dzisiaj te pierwsze, początkowe formy wtajemniczenia mogą oddziaływać tak, jak oddziaływały około 2000 lat temu? Czy mogą mieć podobny wpływ na współcześnie żyjące dzieci i młodzieź? Jak powiązać charakter pierwotnych katechez z potrzebami katechezy dzisiejszej?

2. Na temat Cyryla Jerozolimskiego (jego życia i działalności) nie zachowało się zbyt wiele informacji. Nie znamy do dziś daty i miejsca jego urodzenia. Wiadomo, że był duchownym w czasach biskupa Maksyma (być może sam był biskupem - ale nie jest to do końca wyjaśnione przez historyków) ${ }^{3}$. Najważniejszy „ślad" po nim to Katechez $y^{4}$, jeden z najcenniejszych skarbów starożytności chrześcijańskiej, który jest głównym przedmiotem zainteresowania w niniejszym artykule. Dzięki temu Cyryl Jerozolimski należy do najwybitniejszych postaci młodego Kościoła i zarazem do ważnych świadków inicjacji chrześcijańskiej w tym Kościele (wymieniany jest razem z takimi postaciami, jak: Cyprian, Orygenes, Ambroży, Jan Chryzostom, Augustyn $)^{5}$.

Katechezy Cyryla Jerozolimskiego składają się z 24 konferencji, które zostały wygłoszone między 347 a 350 rokiem, a spisane przez jednego ze słuchaczy prawdopodobnie w 351 roku$^{6}$. Można je podzielić na:

- katechezę wstępną - której tematem jest ogólne wprowadzenie ukazujące kandydatowi do chrztu wielkość tego sakramentu,

- 18 katechez chrzcielnych - pierwsze $z$ nich są kontynuacją wprowadzenia, a następne wyjaśniają poszczególne części symbolu wiary,

- 5 katechez mistagogicznych, skierowanych do "oświeconych", czyli ochrzczonych, stanowiące ostatnie wtajemniczenie w misterium chrześcijańskie.

3. Odbiorcami katechez byli ci, którzy na początku Wielkiego Postu przygotowywali się bezpośrednio do przyjęcia sakramentu chrztu w Noc Paschalną.

${ }^{3}$ Por. O.F. Cummings, Cyril of Jerusalem as a postliberal theologian, „Worship” 67 (1993) 155 163; A. Doval, The Location and structure of the Baptistery in the mistagogic Catecheses of Cyril of Jerusalem, „Studia Patristica” 25 (1993) 1-13; J.S. Bojarski, Wstęp, w: Św. Cyryl Jerozolimski, Katechezy przedchrzcielne i mistagogiczne, tłum. W. Kania, oprac. M. Bogucki, BOK 14, Kraków 2000, 5.

${ }^{4}$ W tym artykule wykorzystano wymieniony wyżej przekład Katechez Cyryla Jerozolimskiego.

${ }^{5}$ Por. Cz. Krakowiak, Inicjacja w chrześcijanistwie, EK VII 217; W. Hanc, Ekumeniczny wymiar sakramentów chrześcijaniskiej inicjacji w świetle międzywyznaniowych dialogów doktrynalnych. Studium ekumeniczne, Włocławek 2003, 138-139.

${ }^{6}$ Por. Bojarski, art. cyt., s. 6. 
Podjęli oni już decyzję zostania chrześcijanami i przeszli pierwszy etap przygotowań $w$ grupie katechumenów - audientes. Otrzymali zatem podstawowe wiadomości o tajemnicy wiary w oparciu o naukę Pisma św. i mogli uczestniczyć w początkowych częściach Eucharystii (w liturgii Słowa Bożego i homilii). Katechezy Cyryla Jerozolimskiego skierowane byly przede wszystkim do osób, które znajdowały się już na drugim etapie przygotowań do chrztu (zostały już zapisane na listę kandydatów do tego sakramentu). Stanowiły wówczas odrębną grupę i nazywały się „oświeconymi” - electi lub photizomenoi. Ważnym zadaniem tego drugiego przygotowania bylo tzw. traditio et redditio symboli wiary (pouczenie oraz pamięciowe przyswajanie symbolu i wygłoszenie go z pamięci w obecności biskupa przed chrztem). Warto przy tym zaznaczyć, że niedozwolone było przekazywanie symbolu wiary na piśmie, co wynikało z obawy przed niezrozumieniem niewierzących oraz przed ośmieszeniem nauk i praktyk kościelnych. Myślę, że mogło to nawet budzić większy szacunek wobec poznawanych tajemnic, a także podnosić poczucie odpowiedzialności za przyjęte tajemnice.

Formacja nowych chrześcijan (neofitów - już ochrzczonych) nie kończyła się jednak przyjęciem chrztu. Wysłuchiwali oni jeszcze dodatkowych pouczeń na temat znaczenia obrzędów, jakie dokonały się w Wigilię Wielkanocy. Te nauki wygłaszane były w ciągu tygodnia po uroczystości otrzymania chrztu i odbywały się po liturgiach eucharystycznych. Nazywano je katechezami mistagogicznymi?

4. Katechezy Cyryla Jerozolimskiego - jak to już powiedziano - skierowane były do osób oczekujących na chrzest w okresie Wielkiego Postu (katecheza wstępna i chrzcielne) oraz do neofitów, osób już ochrzczonych (katechezy mistagogiczne). Już we wstępnej katechezie Cyryl podkreśla doniosły charakter nadchodzących wydarzeń, mówiąc do słuchaczy:

„CZymś wielkim jest Chrzest, który was czeka. Jest okupem dla jeńców, odpuszczeniem grzechów, śmiercią winy, odrodzeniem duszy, świetlaną szatą, świętą i nienaruszalną pieczęcią, powozem do nieba, rozkoszą raju, prawem obywatelstwa w królestwie, darem dziecięctwa"8.

Widzimy, że Cyryl traktował kandydatow do chrztu wyjątkowo. Wspominał przy tym różne praktyki, które łączyły się z przygotowaniem do chrztu (były uzupełnieniem głoszonych nauk). Nawiązywał do nich w poleceniu: „Pobożnie przyjmij egzorcyzmy!"9 . Nie tylko egzorcyzmy, ale także wyznawanie grzechów

${ }^{7}$ Por. A. Fetkowski - M. Marczewski, Co to jest katechumenat?, AK 88 (1977) 183-184; J.S. Bojarski, art. cyt., s. 9-10.

${ }^{8}$ Procatechesis 16, PG 33, 360A, BOK 14, 26.

${ }^{9}$ Procatechesis 9, PG 33, 348A, BOK 14, 22. 
i modlitwę („Módl się częściej, aby Bóg zaszczycił cię niebieskimi i nieśmiertelnymi tajemnicami! ${ }^{10}$ ) można rozumieć jako środki wychowawcze, które dawały podstawę do uznania chrześcijaństwa za swoją religię.

Po katechezie wstępnej następował szereg katechez chrzcielnych, które były rozwinięciem zapowiadanych przez Cyryla nauk o tajemnicach życia chrześcijańskiego. Poza ogólnymi uwagami o tych tajemnicach, podkreślał w nich potrzebę wiary i dobrych uczynków, wzywal do pokuty, modlitwy i gotowości wyznania win. Później, pamiętając o konsekwentnej obronie przed herezjami, pogaństwem, żydostwem, prezentował dokładnie chrześcijańską doktrynę zgodnie $z$ symbolami wiary. Mówił o Bogu i Jego przymiotach, wyjaśniał istotę Trójcy Świętej, przedstawiał Boga jako Tego, który jest bez początku i bez końca, wszędzie obecny, sprawiedliwy i dobry ${ }^{11}$. Same tytuły głoszonych katechez wskazują na zgodność nauki Cyryla z podstawowymi prawdami wiary (katechezy: 6-12 po kolei wyjaśniają znaczenie artykułów: „Wierzę w jednego Boga”, „O Bogu Ojcu”, „Wszechmogący”, „W Stworzyciela nieba i ziemi oraz wszystkich rzeczy widzialnych", „I w jednego Pana Jezusa Chrystusa”, „W jednorodzonego Syna Bożego”, „Który przyjął cialo i stał się człowiekiem"). Słuchacze tych pouczeń mogli zapewne odczuć głębię przekazywanych tajemnic, zwłaszcza, że Cyryl nawiązywał do Pisma świętego (jego mowy pełne są odniesień do przypowieści Jezusa i wspomnień apostolów). Pełna powagi jest też katecheza XIII: „Ukrzyżowan i pogrzebion”, w której występuje postać umęczonego Zbawiciela i Krzyż. Swoją mowę rozpoczyna w niej od słów: „Chlubą dla Kościoła katolickiego jest cała działalność Chrystusa, ale chlubą nad chlubami jest krzyż" ${ }^{2}$. Przekonywał słuchaczy o dobrowolnym podjęciu cierpienia przez Jezusa i ukazywał sens tej decyzji. W następnej katechezie wprowadzał juz w radosny nastrój zmartwychwstania. Warto zauważyć, że Cyryl, w głoszonych chrzcielnych katechezach, poświęcal sporo miejsca Duchowi Swiętemu. W katechezie III: „O chrzcie” podkreśla znaczenie i moc działania Ducha Świętego w akcie oczyszczenia człowieka z grzechów. Treść katechez XVI i XVII („W jednego Ducha Świętego Pocieszyciela, który mówil przez proroków”, "O Duchu Świętym”) była w całości przeznaczona na rozważania o Duchu Świętym. Zachęcał też „oświeconych", aby prawdziwie uwierzyli w zmartwychwstanie umarłych i życie wieczne ${ }^{13}$. Posługiwał się przy tym porównaniami wierzeń pogan i wiary chrześcijan, która stanowi rzeczywisty fundament, oparcie, nadaje sens działaniom i pracy człowieka. Wszyscy, którzy uwierzą i wyznają wiarę w słowa głoszone przez Jezusa (a przekazane w Katechezach) powinni jeszcze zrozumieć i wyznać

${ }^{10}$ Procatechesis 16, PG 33, 361A, BOK 14, 26.

11 Por. W. Kania, Istotne cechy katechezy św. Cyryla Jerozolimskiego, VoxP 10 (1990) z. 18, 76.

12 Catechesis XIII 1, PG 33, 772A, BOK 14, 185.

${ }^{13}$ Por. Catechesis XVIII 22-35. 
wiarę „w jeden, święty powszechny Kościól”14. Uzasadnił też konieczność życia w „zgromadzeniu", powołując się przy tym na słowa Pisma świętego (Kpł 8, 3; Pwt 4, 10; Ps 67, 27; Mt 16, 18 itp.).

Cyryl Jerozolimski często nawiązywał oraz wspominał w krótkich podsumowaniach treści przekazane podczas wcześniejszych katechez. Sprawiało to, ze otrzymywana nauka łączyła się w całość, ukazując ciągłość poznawanych wiadomości. Jego Katechezy realizowały założenia inicjacji chrześcijańskiej w starożytnym Kościele. Przybliżały symbol wiary, dzięki czemu jego pamięciowe przyswojenie nie prowadziło do bezmyślnego, mechanicznego odtwarzania. Kandydaci do przyjęcia sakramentu chrztu, z każdą kolejną katechezą, przyblizali się do zrozumienia, lub choćby przyjęcia wiarą, wysłuchiwanych prawd.

Po takim przygotowaniu nadchodził czas uroczystego chrztu w Wigilię Paschalną. „Oświeceni” nie otrzymali jednak dotąd szczegółowej nauki o tym sakramencie. Czas jej przekazania przeznaczony był na tydzień po Wielkanocy (było to zgodne z koniecznością zachowania tajemnicy - tzw. disciplina arcani). Pięć katechez mistagogicznych Cyryla stanowiło właśnie ostateczne wprowadzenie w tajemnice, w których przypominał on neofitom niedawno przeżyte wydarzenia - oczyszczenie z grzechów w kąpieli odrodzenia, pieczęć wspólnoty z Duchem Świętym w bierzmowaniu, oraz moc i skuteczność tajemnicy ołtarza. Uczyły one również, jak należy uczestniczyć w ofierze Mszy świętej. Istotne jest tu zauważenie znaczenia rytów chrzcielnych, które Cyryl omówił w II katechezie mistagogicznej. Dążył on do pogłębienia rozumienia obrzędów, w jakich uczestniczyli neofici podczas liturgii wielkanocnej. Przybliżał język symbolu, w jakim została wyrażona tajemnica przekazania „nowego życia" (wprowadzenia na drogę wewnętrznego przeobrażenia, na drogę „odrodzenia”). Wyjaśniał między innymi gesty: zdjęcia szat, wylania oleju egzorcyzmującego, trzykrotnego zanurzenia się w wodzie ${ }^{15}$. Czytając grupę katechez mistagogicznych, widzimy, że Cyryl dostrzegał sens i znaczenie tego procesu, który prowadził do ostatecznego wtajemniczenia w misterium chrześcijańskie. Sam przy tym przyznal, że $\mathrm{z}$ niecierpliwością czekał na okazję wyjawienia wszystkich prawd:

„Już dawno pragnąlem (...) wyjaśnić wam te duchowe, niebieskie tajemnice. Ale ponieważ dobrze wiedziałem, że więcej wierzy się oczom, aniżeli uszom, czekałem aż do dnia dzisiejszego, by was - skoro dzięki temu, coście niedawno przeżyli, lepiej przygotowaliście się do nauki - poprowadzić na jaśniejszą i wonniejszą łąkę tego raju"16.

\footnotetext{
${ }^{14}$ Por. Catechesis XVIII 22-35.

${ }^{15}$ Por. T. Kaczmarek, Ryty chrzcielne jako naśladowanie tajemnic paschalnych wediug II katechezy mistagogicznej Cyryla Jerozolimskiego, VoxP 10 (1990) z. 18, 83.

${ }^{16}$ Catechesis XIX 1, PG 33, 1065A, BOK 14, 319.
} 
Wypływa stąd mądrość Cyryla, który uczył, ze tajemnice wiary chrześcijańskiej odznaczają się taką głębią i wielkością, że samo ich rozumowe wyjaśnianie niewiele daje. Trzeba czekać na doświadczenie mocy sakramentu, aby możliwe było choć częściowe pojęcie i przyjęcie tej tajemnicy. Dzięki temu systematycznemu i integralnemu przekazowi doktryny chrześcijańskiej, Katechezy Cyryla Jerozolimskiego miały znaczący udział we wprowadzeniu w pełnię chrześcijańskiego życia. Są one także ważnym świadectwem o życiu pierwotnego Kościoła.

5. Nie należy na pewno pomijać znaczenia różnych cech charakteryzujących nauczanie Cyryla. Dostosowane ono było do audytorium, czyli do słuchaczy Katechez. Należeli do nich w większości przedstawiciele prostego ludu (nie posiadający wykształcenia, nie umiejący czytać). Dlatego też mają one charakter prostych katechez, niewyszukany styl i bezpośredni ton. Przemawiał do wszystkich w sposób bardzo prosty, używał wielu odniesień do tematów biblijnych, w wyjaśnianiu prawd wiary posługiwał się prostymi obrazami. Unikał poza tym skrajności w swoim nauczaniu. Dowodem tego jest jego stanowisko w sporze o ważność ciała: uważal, że chociaż ciało wiedzie do grzechu, to nie należy go poniżać, bo stanowi ono jakby „narzędzie" i "szatę" duszy. Nie przywiązywal zbytniej uwagi do spraw filozoficznych czy teologicznych ${ }^{17}$.

6. Omówione powyżej elementy inicjacji chrześcijańskiej opartej na Katechezach Cyryla Jerozolimskiego mogą zrodzić pytania: jaki jest sens śledzenia etapów wtajemniczenia w życie Kościoła starożytnego? Czy takie poszukiwania mogą doprowadzić do odkrycia praktycznych wskazówek dla katechezy współczesnej? Zdaniem Jacka Bojarskiego „,katechezy Cyryla Jerozolimskiego należą do najbardziej aktualnych pism starożytności chrześcijańskiej”" ${ }^{\prime 18}$. Na ich podstawie lepiej uświadamiamy sobie znaczenie problemów świata wspólczesnego, które mają wpływ na kształtowanie się zadań dzisiejszej katechezy. Zadania te różnią się od tych, które istniały przed prawie XX wiekami. Podobnie inne były sposoby, środki ich realizacji w Kościele starożytnym niż we współczesnym. Cyryl Jerozolimski przekazuje jednak w swych Katechezach potrzebną (niezależnie od czasu i miejsca) wrażliwość na ducha i zasady, które powinny stanowić fundament każdej katechezy ${ }^{19}$. Czytając te Katechezy upewniamy się, że forma inicjacji w czasach Cyryla Jerozolimskiego była formą pedagogicznie ważną, bo rzeczywiście prowadziła do głębszego poznania, zaangażowania się w życie pierwotnych wspólnot kościelnych. Inicjacja była ściśle związana ze wspólnotą - we wspólnocie się dokonywata i do wspólnoty miala

17 Por. Kania, dz. cyt., s. 78-80.

18 Bojarski, art. cyt., s. 15.

19 Por. tamże, s. 16. 
ostatecznie wprowadzać. Dzisiaj wraca się do tematu inicjacji właśnie po to, by przypomnieć sobie rolę wspólnoty, wprowadzanie do niej. W procesie inicjacji istotne jest też ciągłe odkrywanie samej wiedzy religijnej o sakramentach. Razem z wiarą prowadzi ona do pełni chrześcijańskiego życia.

\title{
THE WAY OF CHRISTIAN INITIATION IN ANTIQUE CHRISTIAN CHURCH BASED ON CYRIL OF JERUSALEM'S CATECHESIS
}

\author{
(Summary)
}

Cyryl is one of the most prominent persons of young Christian Church and also most important witnesses of Christian initiation in this Church. He's an author of Catechesis - one of most valuable treasures and most current writings of Christian antiquity as far as message is concerned. The Catechesis clearly introduce the way of Christian initiation, the way of initiation into subsequent truths of beliefs, which I will attempt to discover and present. They also deliver necessary (independent from time and places) sensibility of spirit and Christian rules.

In present article I will try to answer the questions: whether nowadays this first, initial forms of initiation, about which we inquire from described here Catechesis, are able to influence as considerably, as they did 2000 years ago? Can they similarly affect the manners of modern children and youth? 